\title{
Seleksi Ketahanan Ubi Jalar Madu Genotipe Fl terhadap Penyakit Kudis (Sphaceloma batatas Saw.)
}

\author{
Fitri Widiantini* dan Endah Yulia \\ Departemen Hama dan Penyakit Tumbuhan, \\ Fakultas Pertanian, Universitas Padjadjaran \\ Jl. Raya Bandung-Sumedang KM 21, Jatinangor \\ 45363 \\ *email: fitri.widiantini@unpad.ac.id
}

\author{
Aina Anna Roosda dan Agung Karuniawan** \\ Departemen Budidaya Pertanian, Fakultas \\ Pertanian, Universitas Padjadjaran \\ Jl. Raya Bandung-Sumedang KM 21, Jatinangor \\ 45363 \\ email:akaruni1@yahoo.com
}

\begin{abstract}
Resistant Selection of Sweet Potato Genotypes F1 against Scab Disease (Sphaceloma batatas)

Variety of sweet potato in Indonesia is very diversed which is an advantage to develop sweet potato varieties. However, local sweet potato often replaced with higher economic value varieties. The aim of this research was to determine the resistant ability of genotype $F_{1}$ from open pollination of local sweet potato landraces against scab disease (Sphaceloma batatas). As much as 661 genotypes $\mathrm{F}_{1}$ were grown on research plantation centre at Ciparanje, Faculty of Agriculture Universitas Padjadjaran. The experiment was done using randomized blocked augmented design. The result demonstrated that genotypes F1 as results of crossing over between local varieties of sweet potatoes had high resistance against scab. This was demonstrated by more than $50 \%$ of the assessed population were resistant to scab as showed by low value of diseases severity. However, growing those genotypes at different seasons and locations need to be done to determine the resistance stability.
\end{abstract}

Keywords: sweet potato, scab, Sphaceloma batatas

\begin{abstract}
ABSTRAK
Varietas lokal ubi jalar di Indonesia sangat beragam. Keragaman yang ada tersebut sangat bermanfaat dalam pengembangan ubi jalar. Namun, varietas lokal semakin tergeser seiring dengan nilai ekonomi yang lebih menguntungkan. Tujuan dari penelitian ini adalah untuk mngetahui ketahanan genotipe-genotipe $\mathrm{F}_{1}$ ubi jalar madu hasil dari open pollination dari aksesi-aksesi ubi jalar lokal terhadap penyakit kudis (Sphaceloma batatas). Sebanyak 661 genotpe $\mathrm{F}_{1}$ beserta aksesinya digunakan dalam penelitian ini. Percobaan dilaksanakan di kebun percobaan Ciparanje Fakultas Pertanian Universitas Padjadjaran pada bulan Januari 2013-Juni 2013. Percobaan disusun dengan menggunakan rancanga acak dengan perluasan (augmented design). Pengamatan dilakukan dengan menghitung intesitas serangan penyakit kudis dengan interval 30 hari. Hasil percobaan menunjukkan bahwa genotipe-genotipe $\mathrm{F}_{1}$ yang diuji menunjukkan potensi ketahanan terhadap serangan penyakit kudis. Hal ini ditunjukkan dengan banyaknya genotipe ubi jalar yang relatif tahan terhadap serangan penyakit kudis. Lebih dari 50\% dari genotipe $\mathrm{F}_{1}$ ubi jalar yang diuji tahan terhadap serangan penyakit kudis yang ditunjukkan dengan rendahnya nilai assessment serangan penyakit. Pengujian di berbagai musim tanam dan lokasi perlu dilakukan untuk mengetahui kestabilan ketahanan yang dimilik oleh genotipe-genotipe $\mathrm{F}_{1}$ tersebut.
\end{abstract}

Kata kunci: ubi jalar madu, kudis, Sphaceloma batatas 


\section{PENDAHULUAN}

Varietas lokal merupakan salah satu aset plasma nutfah yang harus dilestarikan. Varietas lokal adalah kumpulan tanaman yang memiliki kesamaan fenotip dan kandungan tertentu yang beradaptasi baik pada suatu wilayah tertentu sehingga memiliki nilai ekonomi bagi wilayah tersebut (Kiessling, 1912 dikutip Zeven, 1998). Namun, semakin berkembangnya penelitian dan terdapat proses seleksi, terkadang varietas lokal tergeser oleh varietas unggul yang dirancang oleh peneliti. Pergeseran varietas lokal juga dapat disebabkan oleh introduksi tanpa sengaja oleh manusia, juga penyerbukan yang terjadi secara outcrossing (Jones et al., 2008). Salah satu cara untuk melestarikan varietas lokal adalah dengan perbaikan kualitas dan kuantitas pada keturunan selanjutnya.

Ubi jalar madu merupakan salah satu varietas lokal yang rentan terhadap cekaman biotik. Hasil penelitian tim Fakultas Pertanian Unpad sejak tahun 2008, populasi asli ubi jalar madu yang pada umumnya disebut ubi Cilembu telah ditinggalkan. Petani sebagai pelaku produksi mengaku ubi jalar madu Cilembu mengalami penurunan daya hasil (hanya 7-10 toh/h dari sebelumnya 20 ton/ha), umur panen yang panjang (6- 8 bulan), semakin peka terhadap penyakit kudis (di lahan) dan penyakit totol hitam (pasca panen) (Maulana, 2011). Cekaman biotik berupa penyakit dapat menurunkan kualitas dan kuantitas ubi jalar madu sehingga dapat memicu kepunahan.

Penyakit kudis merupakan penyakit utama pada tanaman ubi jalar. Filipina kehilangan hasil ubi jalar sebesar 50\% (Divinagracia et al. 1984). Efek serangan penyakit kudis tersebut dapat menurunkan hasil sebesar $25 \%$ saat tanaman terinfeksi dua minggu (Nayga \& Gapasin 1986). Serangan penyakit kudis pun mempengaruhi produksi ubi jalar di Indonesia (Sudarijanto et al. 1996). Efek yang sangat besar disebabkan oleh penyakit kudis tersebut dapat menurunkan hasil sehingga menurunkan produksi petani lokal.

Pengendalian penyakit kudis umumnya mengandalkan pada penggunaan varietas tahan (Juanda dan Cahyono, 2000). Akan tetapi hingga saat ini belum diperoleh ubi jalar madu yang tahan terhadap serangan penyakit kudis. Ubi jalar madu memiliki keragaman yang tinggi. Jawa Barat merupakan wilayah yang memiliki keragaman ubi jalar yang tinggi (Chandria dkk., 2009). Desa Cilembu, Kabupaten Sumedang, keragaman ubi jalar madu sangat beragam (Rahmannisa dkk., 2011). Keragaman varietas sebagai plasma nutfah akan mempermudah perakitan varietas baru (Fehr, 1987). Keberadaan sumber gen yang beragam tersebut dapat dimanfaatkan sebagai sumber perakitan varietas baru yang unggul.

Laboratorium Pemuliaan Tanaman Fakultas Pertanian telah mengoleksi aksesi-aksesi ubi jalar madu yang berada di Kabupaten Sumedang. Penentuan tetua untuk persilangan polycrossing dilaporkan oleh Roosda dkk (2013). Dari hasil persilangan tersebut didapatkan 600 biji $F_{1}$ dari 47 aksesi ubi jalar madu. Oleh karena diperlukan seleksi ketahanan genotipe $F_{1}$ ubi jalar madu tersebut terhadap penyakit. Penelitian ini melaporkan hasil evaluasi ketahanan genotipe $F_{1}$ ubi jalar madu hasil polycrossing terhadap serangan penyakit kudis (S. batatas).

\section{BAHAN DAN METODE}

\section{Identifikasi patogen penyebab penyakit kudis pada tanaman ubi jalar madu \\ Identifikasi patogen yang menyerang} tanaman dilakukan dengan pengambilan sampel tanaman ubi jalar madu yang menunjukkan gejala terserang oleh penyakit kudis. Sampel tanaman dipetik dan dibungkus dengan menggunakan kertas koran atau tissue untuk menjaga kelembaban selama transportasi dari lapangan menuju laboratorium. Apabila identifikasi tidak dilakukan langsung, maka sampel disimpan dalam lemari pendingin sampai pengujian dilakukan. Penyediaan prepaprat dilakukan dengan menempelkan selotip pada daun atau batang yang menunjukkan gejala terserang penyakit kudis. Selotip tersebut kemudian ditempelkan pada object glass yang sebelumnya telah ditetesi methylene blue untuk kemudian diamati di bawah mikroskop.

\section{Pengolahan lahan dan penanaman ubi jalar madu}

Penanaman genotipe F1 ubi jalar madu beserta aksesinya dilakukan di kebun percobaan Ciparanje Fakultas Pertanian Universitas Padjadjaran dengan ketinggian $700 \mathrm{dpl}$ (di atas permukaan laut). Penelitian menggunakan metode eksperimen yang disusun berdasarkan rancangan acak kelompok perluasan (augmented design). Sebanyak $600 \mathrm{~F}_{1}$ ubi jalar madu dan 39 aksesi ubi jalar madu sebagai entri/yang diuji 
tanpa ulangan dan 8 aksesi ubi jalar madu sebagai cek atau kontrol diulang 2 kali. Sehingga terdapat 647 plot percobaan. Masing-masing genotip dan aksesi ditanam pada satu guludan dengan panjang guludan 1 meter dengan jarak tanam didalam guludan $20 \mathrm{~cm}$. Jarak antar guludan $50 \mathrm{~cm}$. Pemeliharaan dilakukan dengan penyiangan gulma dan penyiraman.

Sebanyak 9 genotipe digunakan sebagai check atau pembanding dan ditanam pada kedua blok perlakuan sebagai ulangan, sedangkan aksesi dan genotipe lainnya tidak dilakukan ulangan. Kesembilan genotipe tersebut adalah HAR, NK102, NIR2, NIR C, NK114, CTJ-02, T3, NK111 dan GKAW. HAR, NIR2, NIR C, CTJ-02, T3 dan GKAW dipilih sebagai check karena pada awal pengujian pemilihan seeding ubi jalar madu, keenam genotipe ini menunjukkan intensitas serangan penyakit yang relatif lebih rendah dibandingkan dengan genotipe-genotipe lainnya dan dikategorikan sebagai genotipe ubi jalar yang relatif tahan terhadap serangan penyakit kudis. Sedangkan NK102, NK114 dan NK-111 merupakan genotipe ubi jalar madu asli Cilembu yang menunjukkan intensitas serangan penyakit kudis yang relatif tinggi dibandingkan dengan genotipe-genotipe lainnya sehingga dikategorikan sebagai genotipe yang rentan terhadap serangan penyakit kudis (Roosda dkk, 2013).

\section{Inokulasi buatan $S$. batatas}

Lokasi percobaan merupakan daerah endemik penyakit kudis, akan tetapi untuk meningkatkan tingkat serangan penyakit kudis maka dilakukan inokulasi buatan. Sumber inokulum dipersiapkan dengan mengikuti metode Lenne et al. (1994). Sporulasi $S$. batatas dipicu dengan merendam pangkal daun yang terserang kudis setinggi $2 \mathrm{~cm}$ dalam larutan gula fisiologis $2 \%(\mathrm{w} / \mathrm{v})$. Rendaman didiamkan selama satu malam. Spora kemudian dipanen dengan merendam daun kembali dalam akuades. Kerapatan spora dihitung pada kerapatan $10^{4}$ spora/ml. Suspensi spore tersebut kemudian disemprotkan pada tanaman ubi jalar hingga run off.

\section{Pengamatan}

Pengamatan dilakukan dengan menghitung derajat keparahan penyakit atau Disease Severity (DS). Persentase luasan bagian tanaman yang terserang penyakit kudis yang dihitung dengan menggunakan ujung terminal dari tanaman ubi sepanjang lebih kurang $50 \mathrm{~cm}$ yang berasal dari tanaman pada masing-masing plot. Skoring disease severity dihitung dengan menggunakan kategori $0-5$ sebagai berikut: $0=$ tanaman bebas dari penyakit; $1=$ kurang dari 5 bercak scab per $10 \mathrm{~cm}$ batang dan tangkai daun, tidak ada perubahan bentu daun; $2=5-50$ bercak scab per $10 \mathrm{~cm}$ batang dan tangkai daun, bercak pada tulang daun menyebabkan sedikit perubahan bentuk daun; $3=>50$ bercak scab per $10 \mathrm{~cm}$ batang dan tangkai daun, daun mulai berubah bentuk; 4 = bercak scab memenuhi hamper sebagian besar area batang dan tangkai daun, daun berubah bentuk; dan 5 = daun mati, ujung tanaman berubah bentuk dan jaringan meristem mati. Kemudian evaluasi disease severity terakhir kembali dilakukan pada plot pertanaman menjelang panen, dengan menggunakan skoring sebagai berikut: $0=$ semua tanaman dalam plot tampak sehat; $1=$ ditemukan adanya bercak tetapi tidak terlihat adanya perubahan bentuk daun; 2 = tidak ada ujung tanaman yang terlihat berdiri, daun berubah bentuk; 3 = beberapa ujung tanaman tampak berdiri, daun berubah bentuk; 4 = kebanyakkan ujung tanaman tampak berdiri; dan 5 = semua tanaman mati (Ramsey et al., 1988).

\section{HASIL DAN PEMBAHASAN}

\section{Identifikasi patogen penyebab penyakit kudis pada tanaman ubi jalar madu}

Gejala-gejala tanaman ubi jalar yang terserang oleh penyakit kudis dapat dilihat pada Gambar 1. Pada awal serangan terlihat adanya bercak cekung kecil berwarna coklat pada daun (Gambar 1A) atau batang dengan ukuran yang bervariasi antara 1-5 mm. Bercak dapat berbentuk bulat, elips atau lonjong memanjang. Seiring berjalannya waktu kemudian bercak tersebut dapat membesar dengan bersatunya bercakbercak kecil. Pada serangan lanjut bercak kemudian berubah bentuk menjadi seperti berkerak dan terlihat seperti kudis (Gambar 1B). Daun kemudian mengalami perubahan bentuk. Hal ini disebabkan karena daun yang terserang tidak dapat tumbuh kembali, sehingga daun menggulung dan terlihat keriting (Gambar 1B). Daun kemudian terlihat menjadi tegak dan dapat terlihat dari kejauhan (Gambar 1C). 


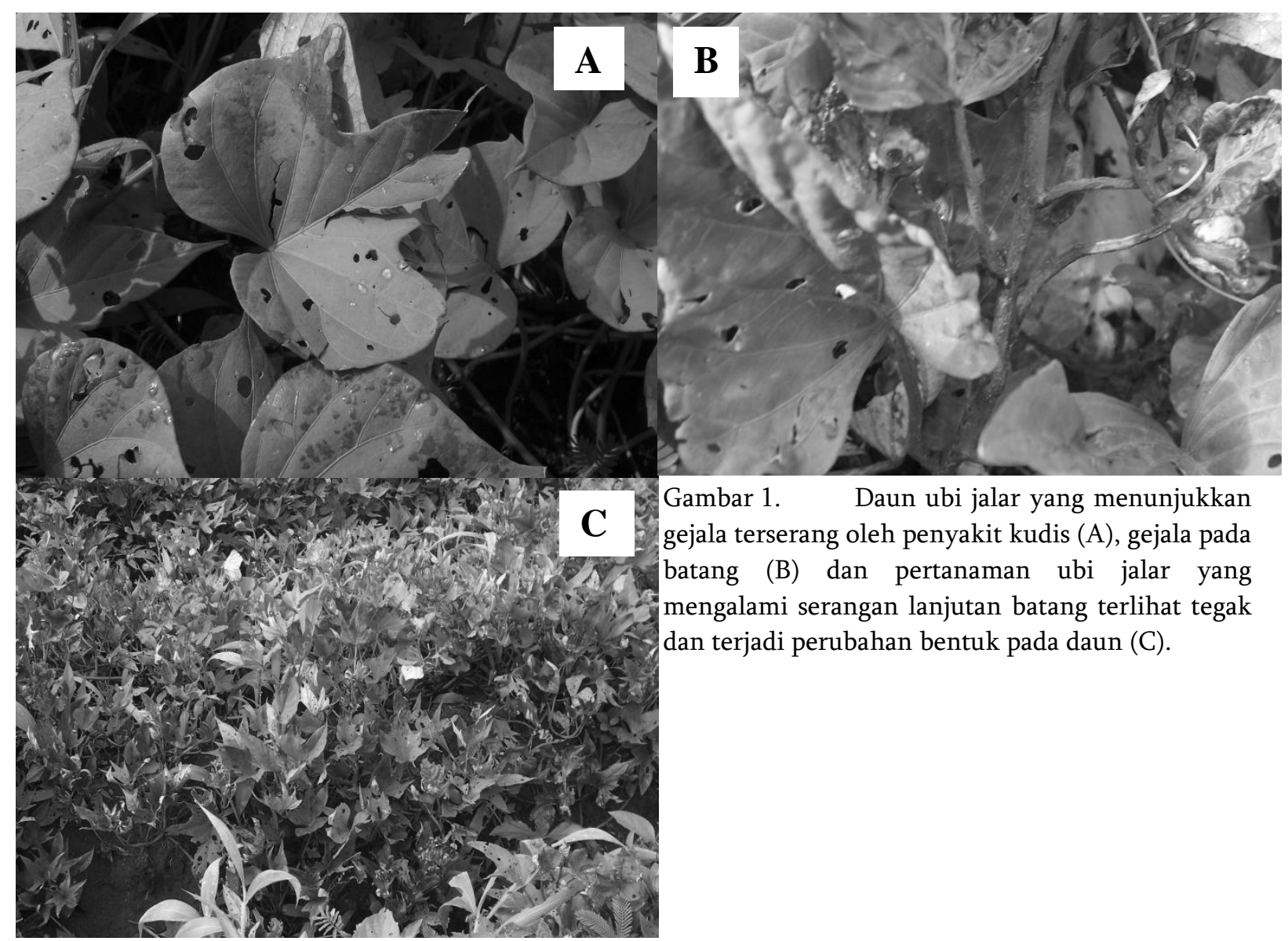

\begin{abstract}
Pengamatan secara mikroskopis menunjukkan bahwa penyakit kudis yang menyerang disebabkan oleh Sphaceloma babatas (anamorph $E$. batatas). Daun dan batang yang terserang oleh penyakit kudis diamati di bawah mikroskop seperti terlihat pada Gambar 2. Bercak pada daun (Gambar 2A) dan batang (Gambar 2B) terlihat menjorok ke dalam dan terlihat adanya struktur yang menonjol ke atas terlihat seperti kepala jarum pentul yang merupakan tubuh buah (aservulus) dari jamur $S$. batatas (Gambar 2C). Badan buah ini tersebar pada permukaan bercak pada tanaman yang terserang. Konidiofor berwarna coklat muda, membentuk palisade yang kompak, terdiri dari satu septa dengan ujung berbentuk lonjong (Gambar 2D). Sedangkan konidia terlihat berbentuk lonjong dengan warna hyaline atau bening (Gambar 2D).
\end{abstract}

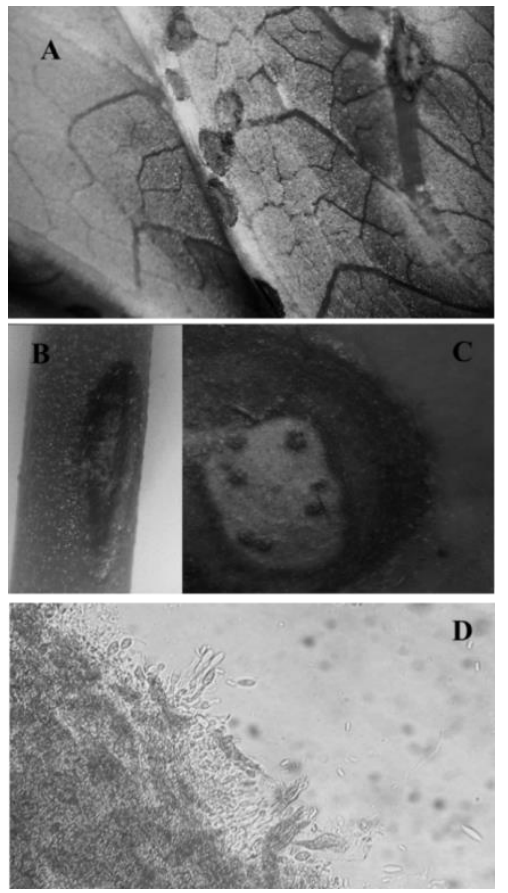

Gambar 2. Pengamatan mikroskopis dari tanaman ubi jalar yang terserang penyakit kudis. Gejala pada daun (A), batang (B), struktur badan buah pada daun yang terserang (C) dan konidia dari $S$. batatas (D). 
Seleksi ketahanan genotipe F1 ubi jalar madu tahan terhadap serangan penyakit kudis ( $S$. batatas)

\section{Pengamatan dilakukan dengan} menghitung intensitas serangan penyakit kudis dengan interval waktu 30 hari. Pengamatan pada 30, 60, 90 dan 120 hari dihitung berdasarkan persentase tanaman terserang sementara pengamatn terakhir pada hari ke-150 dilakukan berdasarkan kondisi morfologi tanaman, apakah ujung tanaman mengalami perubahan menjadi tegak berdiri atau tidak serta terjadi atau tidaknya perubahan daun. Hal ini dibedakan karena pada pengamatan terakhir serangan penyakit kudis sudah parah sehingga tidak dapat dilakukan lagi penghitungan jumlah lesi untuk beberapa genotipe F1 (Ramsey et al., 1988).

Kriteria ketahanan diberikan berdasarkan penelitian Ramsey et al. (1988) pada rata-rata disease severity 150 HST untuk menyeleksi genotip $\mathrm{F}_{1}$ yang tahan dan rentan dengan kriteria disease severity: 0.0 - 0.6 = Sangat Tahan; $0.7-1.3$ = Tahan; $1.4-1.9=$ Agak Tahan; 2.0 - $2.7=$ Agak Rentan; $\geq 2.8=$ Rentan. Berdasarkan hasil pengamatan (Gambar 3) terdapat banyak genotipe F1 yang menunjukkan ketahanannya terhadap serangan penyakit kudis. Sebanyak 50\% genotipe $\mathrm{F}_{1}$ menunjukkan ketahanan yang tinggi (sangat tahan) dengan tidak ditemukannya gejala pada daun maupun batang. Sebanyak 19\% termasuk dalam kategori tahan. Sementara tanaman yang termasuk dalam kategori agak rentan dan rentan masing-masing adalah sebanyak $14 \%$ dan $17 \%$.

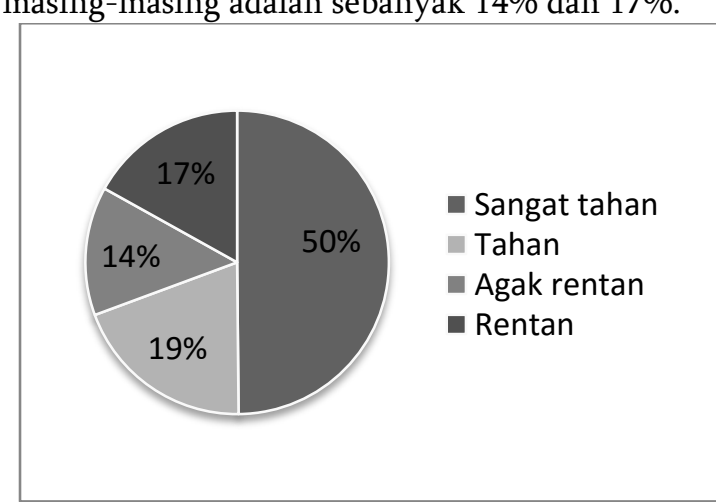

Gambar 3. Persentase jumlah genotipe F1 ubi jalar madu hasil polycrossing sesuai dengan kriteria ketahannya terhadap serangan penyakit kudis.

Ketahanan tanaman terhadap penyakit umumnya dapat dikategorikan sebagai ketahanan yang terhindarkan (escape resistance), tolerant dan resisten. Para pemulia tanaman menggunakan kategori ketahanan yang terakhir untuk dimanfaatkan sebagai sumber ketahanan guna mendapatkan tanaman varietas tahan. Sementara ketahanan yang terhindarkan dan tanaman tolerant relatif tidak memegang peranan penting dalam upaya pemuliaan tanaman. Banyaknya genotipe ubi jalar yang menujukkan ketahanan terhadap serangan penyakit dapat diartikan menjadi dua hal. Yang pertama, genotipe-genotipe tersebut benar-benar tahan serangan penyakit kudis atau yang kedua genotipe-genotipe tersebut terhindarkan dari serangan patogen penyebab penyakit kudis. Sehingga diperlukan pengujian lebih lanjut terutama mengenai identifikasi gen yang berasosiasi dengan ketahanan terhadap penyakit kudis. Seleksi fenotipik yang dikombinasikan dengan penggunaan SSR marker yang berasosiasi dengan gen resisten lebih efektif dalam pengembangan varietas resisten, jika dibandingkan dengan pemilihan keturunan tanaman yang hanya didasarkan pada pemilihan fenotipiknya saja (Zhou et al., 2003).

\section{KESIMPULAN DAN SARAN}

Identifikasi ketahanan tanaman ubi jalar madu terhadap penyakit kudis ( $S$. batatas) ini merupakan penelitian tahap awal untuk medapatkan varietas tanaman ubi jalar madu yang tahan terhadap serangan penyakit kudis. Hasil percobaan menunjukkan bahwa genotipe-genotipe yang diperoleh dari hasil persilangan polycross aksesi-aksesi ubi jalar madu menunjukkan potensi ketahanan terhadap serangan penyakit kudis. Hal ini ditunjukkan dengan banyaknya genotipe ubi jalar yang relatif tahan terhadap serangan penyakit kudis. Sebanyak 50\% dari genotipe $\mathrm{F}_{1}$ ubi jalar yang diuji tahan terhadap serangan penyakit kudis yang ditunjukkan dengan rendahnya nilai assessment serangan penyakit. Akan tetapi hasil percobaan ini masih harus dilakukan penanaman di musim tanam selanjutnya serta pengujian ketahanan di berbagai lokasi untuk mengetehaui kestabilan ketahanan yang dimiliki genotipegenotipe $F_{1}$ tersebut. Selanjutnya konfirmasi secara genetik juga perlu dilakukan untuk mengetahui gen yang berasosiasi dengan ketahanan terhadap penyakit kudis.

\section{UCAPAN TERIMA KASIH}

Penulis mengucapkan terima kasih dan penghargaan setingi-tingginya kepada Kementerian Pendidikan dan Kebudayaan serta LPPM Universitas Padjadjaran atas bantuan hibah 
penelitian sehingga penelitian ini dapat terselenggara dengan baik. Penelitian ini dapat dilaksanakan berkat hibah dana penelitian melalui skema Penelitian Unggulan Perguruan Tinggi (PUPT) dengan kontrak pekerjaan penelitian No 1076/UN6.R/PL/2013.

\section{DAFTAR PUSTAKA}

Ambarsari, I., Sarjana., dan Choliq, A. (2009). Rekomendasi dalam penetapan standar mutu tepung ubi jalar. Balai Pengkajian Teknologi Pertanian (BPTP). Jawa Tengah.

Ames, T., Smit, N. E. J., Braun, A. R., O’Sullivan, J. N., \& Skoglund, L. G. (1997). Sweetpotato: Major $P$ ests , Diseases, and Nutritional Disorders.

Ashkani S., Rafii M.Y., Rusli I., Sariah M., Abdullah S.N.A., Rahim H.A., Latif M.A. (2011) SSRs for marker-assisted selection for blast resistance in rice (Oryza sativa L.). Plant Molecular Biology Reporter 30:79-86.

Buteler, M. I., LaBonte, D. R., Jarret, R. L., \& Macchiavelli, R. E. (2002). Microsatellitebased paternity analysis in polyploid sweetpotato. Journal America, 127(3), 392396.

Chakravarthi B.K., Naravaneni R. (2006) SSR marker based DNA fingerprinting and diversity study in rice (Oryza sativa L.). African Journal of Biotechnology 5:684-688.

Chandria, W., Natawijaya, A., \& Karuniawan, A. (2009). Diversitas genetik plasma nutfah ubi jalar (Ipomea batatas (L.) Lamb) asal Jawa Barat dan Jepang berdasarkan analisis kluster karakter fenotifik. Simposium Dan Kongres Nasional Perhimpunan Ilmu Pemuliaan Indonesia (PERIPI). Bogor.

Commission, S. P. (1991). Sweet Potato Scab (Vol. 24).

De Vicente, M. C., \& Fulton, T. (2003). Using molecular marker technology in studies on plant genetic diversity.

Divinagracia, G. G., Licardo, N. K., \& Aliac, N. P. (1984). Chemical control of stem and foliage scab of sweet potato. Philippine Phytopathology 20 (1-2):8.

Fehr, W. R. (1987). Principles of Cultivar Development. Theory and Technique. Vol.1. Macmillan Publishing Company. NY.

Hasyim, A., dan M. Yusuf.. 2008. Ubi jalar kaya antosianin pilihan pangan sehat. Badan Litbang Pertanian.
He, X., Liu, Q., Ishiki, K., Zhai, H., \& Wang, Y. (2006). Genetic Diversity and Genetic Relationships among Chinese Sweetpotato Landraces Revealed by RAPD and AFLP Markers. Breeding Science, 56, 201-207.

Jones, H., Lister, D. L., Bower, M. a., Leigh, F. J., Smith, L. M., \& Jones, M. K. (2008). Approaches and constraints of using existing landrace and extant plant material to understand agricultural spread in prehistory. Plant Genetic Resources: Characterization and Utilization, 6(02), 98-112. doi:10.1017/S1479262108993138

Karuri, H. W., Ateka, E. M., Amata, R., Nyende, A. B., \& Muigai, A. W. T. (2009). Characterization of Kenyan sweet potato genotypes for SPVD resistance and high dry matter content using simple sequence repeat markers. African Journal of Biotechnology, 8(10), 2169-2175.

Kong Q., Zhang G., Chen W., Zhang Z., Zou X. (2012) EST-SSR markers by sequence alignment in paper Capsicum annuum (Solanaceae). American Journal of Botany:e59-e61.

Lenne, J.M., Sweetmore, A. \& Burstow, A. (1994). Morphological and pathogenic characterisation of Elsinoe batatas: causal agent of sweetpotato scab. pp. 64-66. In: Proceedings of the International Congressfor Plant Protection in the Tropics, Kuala Lumpur, Malaysia, 28-31March 1994.

Maulana, H. (2011). Keragaman Genetik Populasi Outcrossing F1 Ubi Jalar (Ipomoea batatas (L.) Lam) Varietas Lokal dan Cilembu Berdasarkan Analisis Dendogram dan Analisis Komponen Utama (PCA). Skripsi (Tidak dipublikasikan).

Mcgregor, C. E., Miano, D. W., Labonte, D. R., Hoy, M., Clark, C. A., \& Rosa, G. J. M. (2009). Differential gene expression of resistant and susceptible sweetpotato plants after infection with the causal agents of Sweet Potato Virus Disease. Journal America, 134(6), 658-666.

Miano, D. W., LaBonte, D. R., \& Clark, C. a. (2007). Identification of molecular markers associated with sweet potato resistance to sweet potato virus disease in Kenya. Euphytica, 160(1), 15-24. doi:10.1007/s10681-007-9495-2.

Mwanga, R. O. M., Kriegner, A., Cervantes-Flores, J. C., Zhang, D. P., Moyer, J. W., \& Yencho, G. C. (2002). Resistance to Sweetpotato 
Chlorotic Stunt Virus and Sweetpotato Feathery Mottle Virus is mediated by two separate recessive genes in sweetpotato. Journal America, 127(5), 798-806.

Nayga, J. G., \& R. M. Gapasin. (1986). Effect of stem and foliage scab disease on growth and yield of VSP-1 sweet potato variety. Annals of Tropical Research 8:115-122.

Rahmannisa, S. L., Waluyo, B., \& Karuniawan, A. (2011). Keragaman Varietas Ubi Jalar Asal Desa Cilembu Berdasarkan Karakter Kuantitatif di Daerah Jatinangor. Makalah. Seminar Nasional Hortikultura 2011 Kemandirian Produk Hortikultura untuk Memenuhi Pasar Domestik dan Ekspor. Kerjasama Perhimpunan Hortikultura Indonesia (Perhorti), Institut Pertanian Bogor (IPB) dan Balai Penelitian Tanaman Sayuran (BALITSA).

Ramsey M., Vawdrey L., Hardy J. (1988) Scab (Sphaceloma batatas) a new disease of sweet potatoes in Australia: fungicide and cultivar evaluation. Australian Journal of Experimental Agriculture 28:137-141. DOI: http://dx.doi.org/10.1071/EA9880137.

Roosda, A. A., Waluyo, B., Yulia, E., Widiantini, F., \& Karuniawan, A. (2013) Identifikasi ketahanan ubi jalar (Ipomoea batatas (L.) Lam.) lokal terhadap penyakit kudis (Elsinoe batatas) sebagai dasar penentuan tetua persilangan. Seminar Nasional Hasil Penelitian Tanaman Kacang-kacangan dan Umbi-umbian. Malang 23 Mei 2013.

Sharopova N., McMullen M.D., Schultz L., Schroeder S., Sanchez-Villeda H., Gardiner J., Bergstorm D., Houchins K., MeliaHancock S., Musket T., Duru N., Polacco M., Edwards K., Ruff T., Register J.C., Brouwer
C., Thompson R., Velasco R., Chin E., Lee M., Woodman-Clikeman W., Long M.J., Liscum E., Cone K., Davis G., Coe E.H.J. (2002) Development and mapping of SSR markers for maize. Plant Molecular Biology 48:463-481.

Sudarijanto, A., E. A. Martanto, \& F. A. Paiki. (1996). Natural resistance selection of several sweet potato cultivars for scabies infections (Sphaceloma batatas (Saw.) Jenkins et Viegas). Hyphere (Indonesia) 1 (2):54-57.

Thompson, P. G., Hong, L. L., Ukoskit, K., \& Zhu, Z. (1997). Genetic linkage of Randomly Amplified Polymorphic DNA (RAPD) markers in Sweetpotato. Journal America, 122(1), 79-82.

Umi, S., Ricky, L., \& Hapsari, I. (2012). Improving storage root protein content in sweet potato through open-mating pollination. Agrivita, 34 (3), 1-8.

Veasey, E. A., Borges, A., Rosa, M. S., Queirozsilva, J. R., Bressan, E. D. A., \& Peroni, N. (2008). Genetic diversity in Brazilian sweet potato (Ipomoea batatas ( L .) Lam ., Solanales , Convolvulaceae ) landraces assessed with microsatellite markers. Genetics and Molecular Biology, 31, 725733.

Zeven, A. C. (1998). Landraces: A review of definitions and classifications. Euphytica, 104, 127-139.

Zhou W.-C., Kolb F.L., Bai G.-H., Domier L.L., Boze L.K., Smith N.J. (2003) Validation of a major QTL for scab resistance with SSR markers and use of marker-assisted selection in wheat. Plant Breeding 122:40-46. 